\title{
EVALUATION OF THE IN VITRO IMMUNOMODULATORY ACTIVITY OF LIC EXTRACTS OF TRIPLOTAXIS STELLULIFERA (BEUTH.) HUTCH. AND CRASSOCEPHALUM VITELLINUM (BENTH.) S. MOORE
}

\author{
Jinette Ndonkou Nfozon ${ }^{1,5^{*}}$, Monique Odette Kamtchueng ${ }^{1}$, Roland Nkwelle ${ }^{1}$, Jennifer Orwa ${ }^{4}$, Gabriel Oluga \\ Aboge $^{5}$, Moukeu Raymond Simplice ${ }^{6}$, Feudjio Ndemanou Yolande ${ }^{1}$, Fabrice Fekam Boyom ${ }^{3}$ \& Christopher \\ B. Tume ${ }^{1,2 *}$ \\ ${ }^{1}$ Department of Biochemistry, Faculty of Science, University of Dschang, Cameroon \\ ${ }^{2}$ Department of Biochemistry, Faculty of Science, University of Bamenda, Cameroon \\ ${ }^{3}$ Department of Biochemistry, Faculty of Science, University of Yaounde 1, Cameroonse \\ ${ }^{4}$ Center for Traditional Medicine and Drug Research (CTMDR), Kenyata Medical Research Institute (KEMRI), \\ Kenya \\ ${ }^{5}$ Department of Public Health, Pharmacology and Toxicology, University of Nairobi, Kenya. \\ ${ }^{6}$ Institut of Fisheries Sciences of the University of Douala in Yabassi, Cameroon \\ https://doi.org/10.35410/IJAEB.2021.5601
}

\begin{abstract}
This study aimed to evaluate the in vitro immunomodulatory activity of methanolic extracts of Triplotaxis stellulifera and Crassocephalum vitellinum on different parameters on mouse peritoneal macrophages. The effects of the extracts on peritoneal macrophage viability were evaluated using the 3 (4, 5-dimethylthiazole-2-yl)-2, 5 diphenyltetrazolium bromide (MTT) assay. They were further evaluated for the stimulation of nitric oxide (NO) production, lysosomal enzyme activities and pinocytic activity of macrophages, and on macrophage phagocytosis by the nitroblue tetrazolium dye reduction (NBT) assay.

The results showed that methanolic extracts of Triplotaxis stellulifera and Crassocephalum vitellinum stimulated nitric oxide production by lipopolysaccharide-activated macrophages, while no cytotoxic effects were observed. Both extracts significantly $(\mathrm{P}<0.05)$ increased, the activity of lysosomal enzymes, NBT dye reduction and the pinocytic index of macrophages. Furthermore, the methanolic extracts of these plants increased the phagocytic activity of both Lipopoysaccharide-activated and non-activated macrophages.
\end{abstract}

These findings show that the extracts can be potent sources of immunomodulatory agents, although further complementary studies are needed to confirm these finding.

Keywords: Triplotaxis stellulifera, Crassocephalum vitellinum, Macrophages, Phagocytic activity, Immunomodulation.

\section{INTRODUCTION}

The immune system plays a central role in the organism by protecting it from pathogens such as bacteria, viruses, toxins etc (Brown et al., 2007). There are two distinct pathways used by the immune system to accomplish this protective role; the innate and adaptive immune pathways. 
The non-specific innate response is a generalized response to invading pathogens involving the use of several immune cells such as macrophages (Muralidharan and Mandrekar, 2013). Macrophages play an important role in the homeostatic maintenance of the body through the disposal of internal waste materials and tissue repair. To execute its functions, macrophages use several mechanisms among which are phagocytosis. During phagocytosis, some macrophage enzymes such as peroxidase and lysosomal enzymes are activated to kill invading pathogens. Macrophages also produce and release pro-inflammatory cytokines, and chemical mediators such as nitric oxide (NO) which is an important pro-inflammatory mediator (Nagy et al., 2010). NO generated by the inducible isoforms of NO synthase (iNOS) (Posadas et al., 2000) is essential for host innate immune responses to pathogens, and for the regulation of other physiological functions including neurotransmission, vasodilatation and neurotoxicity (MacMicking et al., 1997). NO is thus considered as one of the major effector molecules in the destruction of microorganisms by macrophages (Liu et al., 20017). In some cases, the immune system can be deficient and does not respond properly to the pathogens, such as in the case of HIV/AIDS (O'Brien et al., 2008); and thus needs help to burst or stimulate its function. Modulation by suppressing or stimulating the immune responsiveness can develop, maintain or optimize its function (Kang and Min, 2012).

The use of medicinal plants for immunomodulation has become a subject of scientific investigation worldwide; and it is recognized that immunomodulation by plants could provide an alternative to conventional chemotherapy for a variety of disease conditions (Pattanayak and Mazumder, 2011). Examples of some medicinal plants that have been demonstrated to have immunomodulatory activities by our research team include among others Alchemilla kiwuensis Engl. (Kamtchueng et al., 2013) and Crassocephalum bauchiense (Raymond et al., 2013); but however, most of them are still in the early stages of being studied.

Triplotaxis stellulifera and Crasssocephalum vitellinum are both plants of the Asteraceae family, and are used in traditional medicine in Cameroon. These plants are reportedly used to cure diverse diseases in many African countries. Triplotaxis stellulifera is used as a pain killer, cough medicine, and to treat malaria etc, while Crasssocephalum vitellinum is used both as a vegetable and as medicine. Very little or no scientific works have been carried out on these two plant species to valorize their medicinal and other uses by the local populations. We therefore embarked on the present study to valorize these plants by investigating the immunomodulatory activities of their methanolic extracts on mouse peritoneal macrophages.

\section{MATERIALS AND METHODS}

\subsection{Plant identification and preparation of extract}

Crasssocephalum vitellinum and Triplotaxis stellulifera plant materials were collected from Tombel subdivision, Kupe Manenguba division, South West region of Cameroon, in August 2016. The plants were identified by a botanical expert at the National herbarium in Yaoundé, Cameroon where voucher specimens are stored and registered as 7635/HNC and 20495/HNC respectively. Leaves and stem were dried at room temperature until crisp dry and ground using a laboratory blender. The plant powders $(500 \mathrm{~g})$ were macerated in 2.5 liters of methanol for 48 hours at room temperature with frequent stirring. The methanol extracts were 
filtered using Whatmann filter paper number 1, and the filtrates were concentrated by evaporation using reduced pressure at 40o C in a rotary vacuum evaporator (Büchi R200).

\subsection{Chemicals}

RPMI 1640 powder containing L-glutamine, and New born calf serum (NBCS) were procured from Gibco (Life Technology Corporation, UK); Herpes powder, Penicillinstreptomycin solution, Sodium bicarbonate powder (NaHCO3), MTT (3-[4, 5 dimethylthiazol-2yl]-2, 5-diphenylterazolium bromide), Lipopolysaccharides (LPS) and Triton X-100 were obtained from Sigma Aldrich, Germany; Nitroblue Tetrazolium (NBT) and Paranitrophenylphosphate (pNPP) were procured from Oxford, India; N-1-Naphthylethylene diamine dihydrochloride from England and Sulfanilic acid from Analar; and Dimethyl sulfoxide (DMSO) from FINAR, India.

\subsection{Isolation of murine peritoneal macrophages}

Two millilitres $(2 \mathrm{ml})$ of New born calf serum (NBCS) was injected into the peritoneal cavity of mice. After 3-4 days, the mice were sacrificed and peritoneal macrophages were harvested by peritoneal washing with $10 \mathrm{ml}$ of cold RPMI 1640. The exudate was centrifuged at $1500 \mathrm{rpm}$ at $+4{ }^{\circ} \mathrm{C}$ for 5 minutes. The cell pellet was washed twice by resuspension and centrifugation as above, and finally resuspended in RPMI $164010 \%$ (RPMI 1640 supplemented with $10 \%$ NBCS, 2 mM L-glutamine and penicillin/streptomycin $100 \mathrm{U} / \mathrm{ml}$ ).

\subsection{Macrophage count and cells viability assay}

The macrophage count was determined by using a haemocytometer, and cell viability was tested by the trypan blue dye exclusion technique. Briefly, a given volume of the cell suspension was mixed with an equal volume of $0.4 \%$ trypan blue in PBS and the unstained viable cells as well as the stained unviable cells were determined by microscopic observation and enumeration. The cells were then adjusted to the required cell count per ml (4X104), plated in a 96 well flat bottom culture plate and incubated for $24 \mathrm{hrs}$ at $37 \mathrm{oC}$ in a $5 \% \mathrm{CO} 2$ humidified incubator.

After removing the non-adherent cells, the mono layered macrophages were treated with plant extracts at different concentrations $(333.33,111.11$ and $37.03 \mu \mathrm{g} / \mathrm{ml})$, separately dissolved in complete RPMI medium containing $0.1 \%$ DMSO and maintained for 24 hours at $37 \mathrm{oC}$ in a humidified $5 \% \mathrm{CO} 2$ incubator. Cells activated by LPS $(1 \mathrm{mg} / \mathrm{ml})$ and cells non-treated with extracts were used as controls. In every experiment, three trials with three replicates per concentration were done.

\subsection{Cytotoxicity assay}

In order to assess the cytotoxic effect of the extract on peritoneal macrophages, the 3(4,5-dimethyl-2-thiazolyl)-2,5-diphenyltetrazolium bromide (MTT) reduction assay was used. The underlying principle is that, the yellow tetrazolium salt of MTT is reduced by mitochondrial dehydrogenases in metabolically active live cells to form insoluble purple formazan crystals, which are solubilized by the addition of a detergent (Stockert et al., 2012). After incubation of 
Vol. 06, No. 01; 2021

ISSN: $2456-8643$

macrophages with plant extracts, $20 \mu \mathrm{l}$ of MTT at $5 \mathrm{mg} / \mathrm{ml}$ were added into each well and the cells were again incubated for 4 hours at $37 \mathrm{oC}$ in 5\% saturated humidified CO2. DMSO was then added into each well and the absorbance was read at $492 \mathrm{~nm}$.

\subsection{Nitrite production assay}

Nitric oxide (NO) produced by the macrophages in the culture media was quantified by measuring the nitrite accumulation, an indicator of NO production, by using Griess reagent (Romani et al., 1994). Briefly, macrophages were incubated with extracts as mentioned above and with or without LPS $(1 \mathrm{mg} / \mathrm{ml})$ for 24 hours in $5 \%$ humidified $\mathrm{CO} 2$. Following the incubation, $50 \mu 1$ of the supernatant was mixed with $50 \mu 1$ of Griess reagent (1\% sulfanilamide and $0.1 \%$ naphthylethylenediamine dihydrochloride in 5\% phosphoric acid) in the dark, for 10 minutes at room temperature. The absorbance was then read spectrophotometrically at $540 \mathrm{~nm}$. Fresh culture medium was used as blank in each experiment. A standard curve of absorbance versus nitrite concentration was plotted using serial concentrations of sodium nitrite.

\subsection{Cellular lysosomal enzyme assay}

The cellular lysosomal enzyme activity of macrophages was evaluated by measuring acid phosphatase activity as described (Suzuki et al., 1990). After culturing macrophages in the presence and absence of plant extracts at different concentrations and with or without LPS during 24 hours in a humidified 5\% CO2 incubator, the supernatants were discarded. Twenty microliters $(20 \mu \mathrm{l})$ of $0.1 \%$ Triton X-100 solution was then added into each well and plates were incubated once more for 30 minutes. Thereafter, $100 \mu 1$ of $10 \mathrm{mM}$ paranitrophenyl phosphate (pNPP) and $50 \mathrm{ml}$ of $0.1 \mathrm{M}$ citrate buffer $(\mathrm{pH} 5.0)$ were added into each well and the plates were incubated for 1 hour under the same conditions. Further, $150 \mu 1$ of borate buffer ( $\mathrm{pH} 9.8$ ) were added into each well to stop the reaction and the absorbances were measured at $405 \mathrm{~nm}$ using a microplate reader. The percentage of lysosomal enzyme activity was calculated as follow:

$\%$ lysosomal activity $=\frac{(\text { Do test }- \text { Do control })}{\text { D0 control }} \times 100$

\subsection{Niroblue tetrazolium $(\mathrm{NBT})$ reduction test}

The reduction of NBT dye by macrophages was carried out according to the method described by Manosroi et al. (2006) with small modifications. In brief, macrophages were cultured for 24 hours in 96 well plates at $37{ }^{\circ} \mathrm{C}$ in a humidified $5 \% \mathrm{CO} 2$ incubator, in the presence of different concentrations of plant extracts and with or without LPS. At the end of the incubation period, $40 \mu \mathrm{l}$ of NBT dye in PBS was added to each well and the plates were further incubated for 1 hour. Thereafter, the supernatant was removed and plates were rinsed vigorously with RPMI 1640 medium, washed four times by flushing with $200 \mu \mathrm{l} /$ well of methanol and air dried. Then $120 \mu \mathrm{l}$ of $2 \mathrm{M} \mathrm{KOH}$ and $140 \mu \mathrm{l}$ of DMSO were added to each well. The absorbance of the turquoise blue solution was measured at $570 \mathrm{~nm}$ and NBT reduction percentage was calculated using the formula:

$\% \mathrm{NBT}$ reduction $=(\mathrm{OD}$ test $/ \mathrm{OD}$ control $) \times 100$ 


\subsection{Pinocytic activity}

The pinocytic activity of peritoneal macrophages was measured by the Neutral red uptake method (Repetto et al., 2008). Peritoneal macrophages were cultured at $37^{\circ} \mathrm{C}$ for 24 hours in 96 well plates in the humidified 5\% $\mathrm{CO} 2$ incubator, in the presence of different concentrations of plant extracts and with or without LPS. Following the incubation, the supernatants were removed and $100 \mu 1$ of $0.1 \%$ neutral red solution was added into each well and the plates were further incubated for an additional 3 hours. After the incubation, the dye was discarded and cells were washed twice with PBS. They were fixed with $4 \%$ formaldehyde for 5 minutes, after which the formaldehyde was discarded and replaced by a mixed solution of $1 \%$ acetic acid and $50 \%$ methanol. The plate was then kept under constant agitation for 30 minutes, after which the absorbance was measured at $492 \mathrm{~nm}$ and the pinocytic index (IP) was calculated as:

$\mathrm{IP}=\mathrm{OD}$ test/OD control

\section{Statistical analysis}

All experiments were performed in triplicate and the results were expressed as means \pm S.D. These results were submitted to one way ANOVA test and when differences existed, means were separated using Waller Duncan's multiple range test at 0.05 significance level.

\section{RESULTS}

\subsection{Effect of plant extracts on peritoneal macrophages viability}

The cytotoxic effects of the methanol extracts of Triplotaxis stellulifera and Crassocephalum vitellinum on peritoneal macrophages (PEM) were evaluated using the colorimetric MTT reduction test. No cytotoxicity on PEM was observed following treatment with any of the two extracts as compared to the untrated controls (Fig. 1).
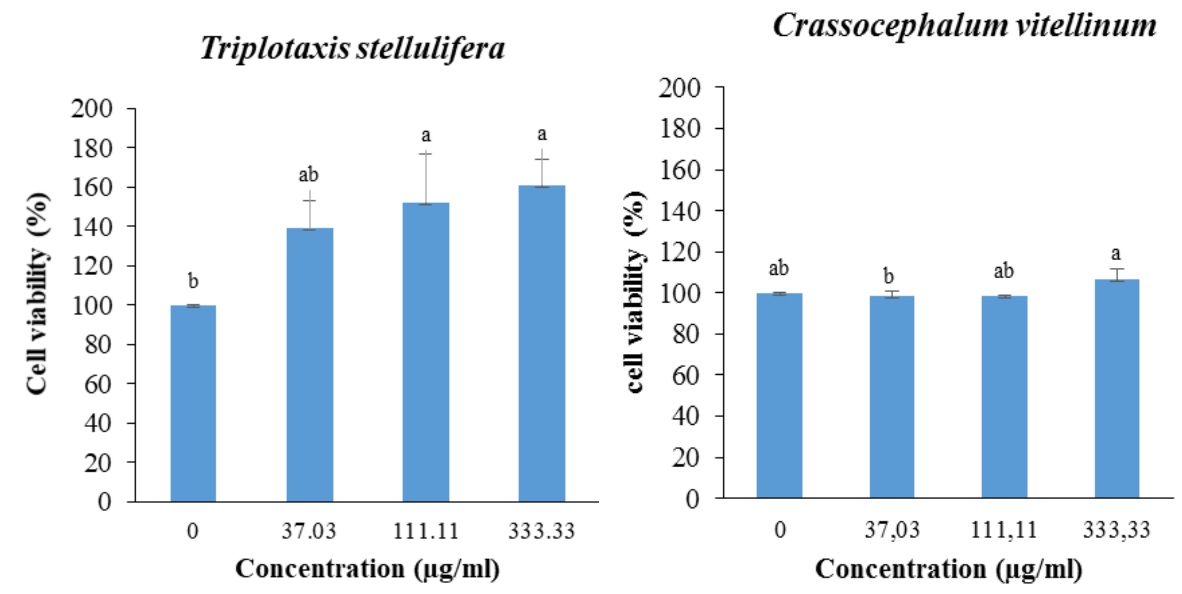

Figure 1: Cytotoxic effect of $T$. stellulifera and $C$. vitellinum on mouse peritoneal macrophages. Results are expressed as mean $\pm \mathrm{SD}(\mathrm{n}=3)$. For a given extract, values of concentration bearing 
different superscript letters are significantly different according to Waller-Duncan test (at $\mathrm{P}<0.05)$.

A stimulation of cell growth was rather observed in the presence of $T$. stellulifera extract as compared to the control.

\subsection{Effect of plant extracts on NO production by peritoneal macrophages}

T. stellulifera and C. vitellinum methanol extracts were tested for their effect on nitric oxide production in culture supernatant of LPS-activated and non-activated PEM. After 24 hours of treatment with extracts on non-activated macrophages, only Crassocephalum vitellinum significantly increased $\mathrm{NO}$ levels as compared to non-treated controls at each concentration (Fig. 2A). As concerns LPS-activated cells, the production of NO was significantly stimulated $(\mathrm{P}<0.05)$ in the presence of both extracts as compared to the LPS-activated positive control (LPS-activated PEM without extracts), in a dose-related manner (Fig. 2B).

A
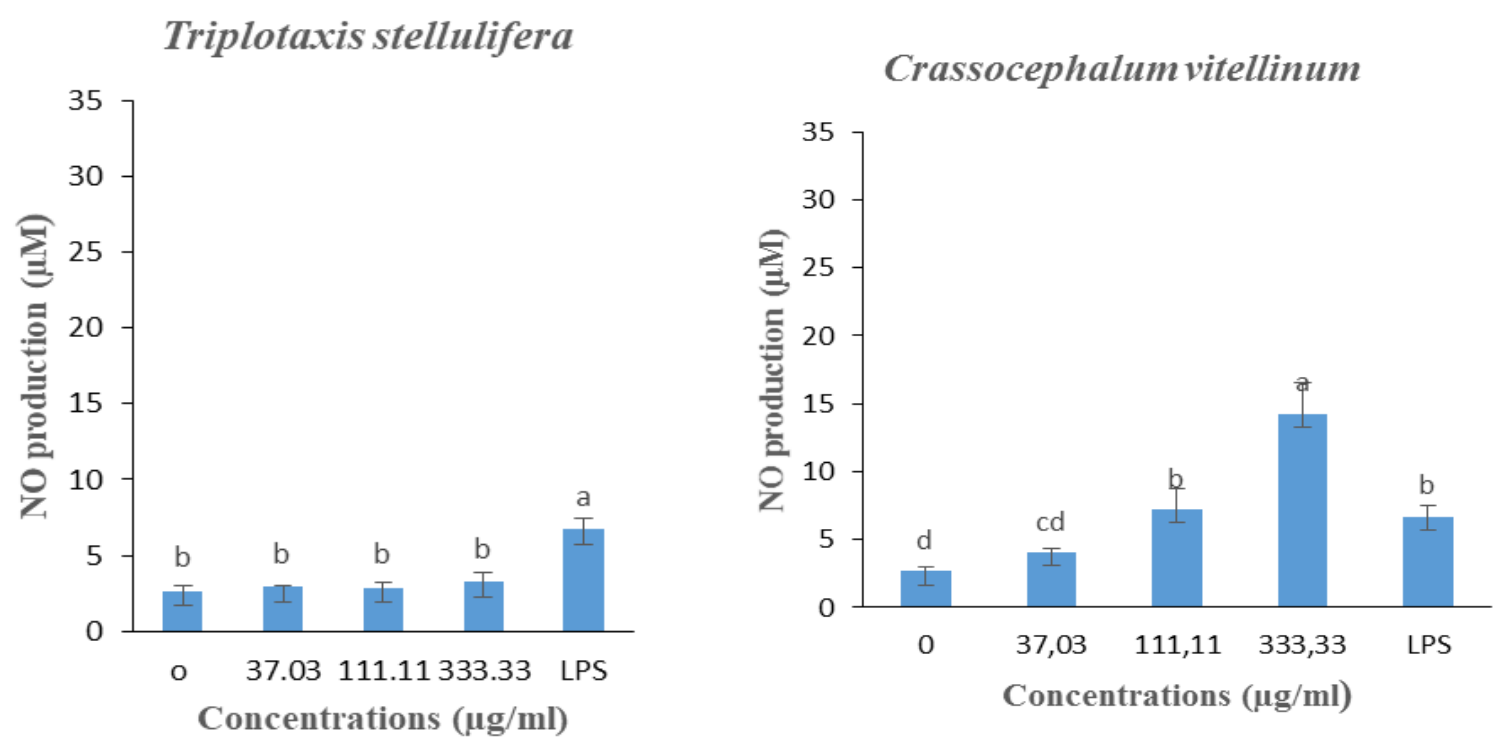
B
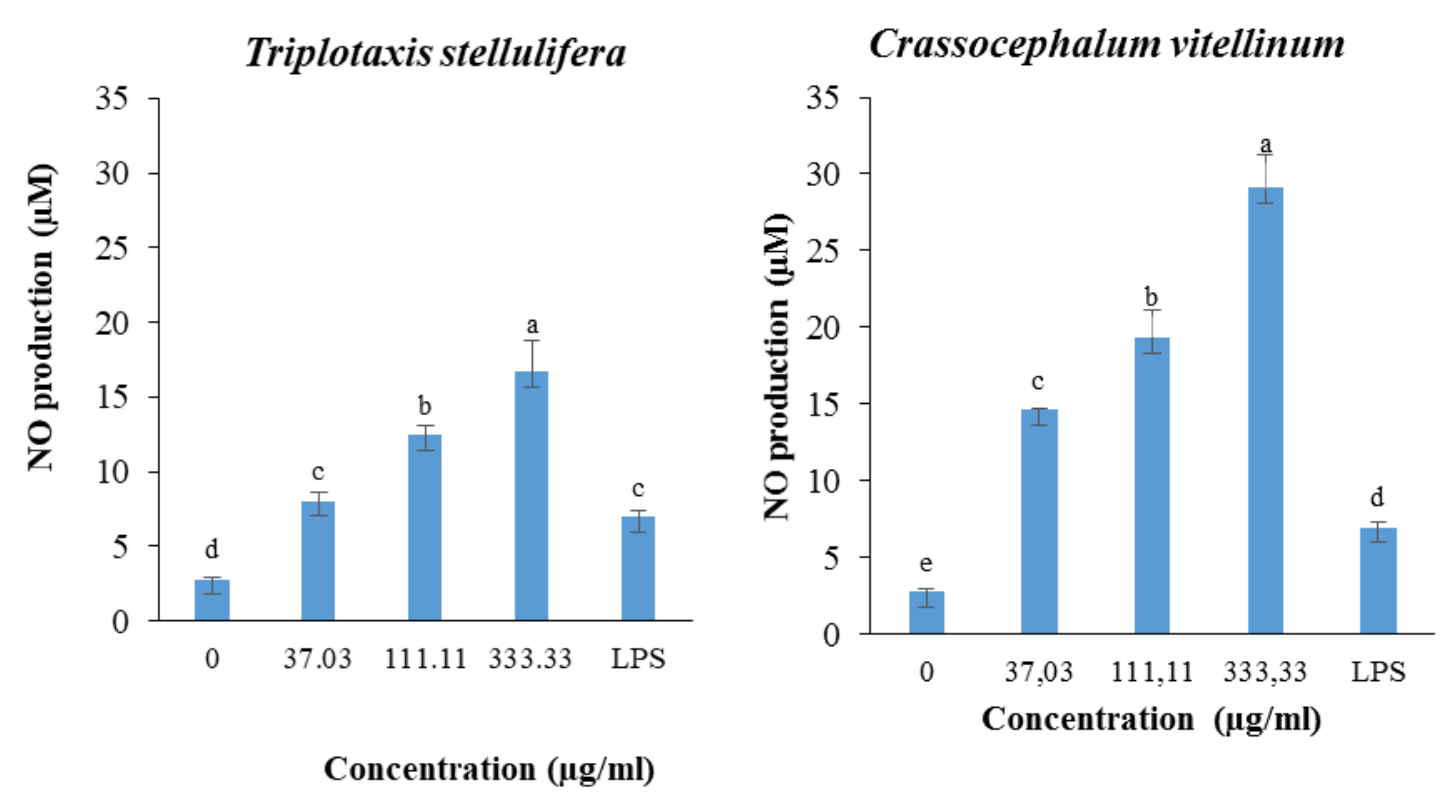

Figure 2: Effect of $T$. stellulifera and $C$. vitellinum extract on NO production. Results are expressed as mean $\pm \mathrm{SD}(\mathrm{n}=3)$. For a given extract, values of concentration bearing different superscript letters are significantly different according to Waller-Duncan test (at $\mathrm{P}<0.05)$.

A: Non-activated (LPS-nä̈ve) cells. B: LPS-activated cells.

\subsection{Effect of plant extracts on lysosomal enzyme activity}

As shown in Fig. 3, T. stellulifera and C. vitellinum methanol extracts significantly increased the lysosomal enzyme activity of non-activated macrophages as compare to nontreated control (Fig. 3A). These plant extracts also significantly enhanced intracellular lysosomal enzyme activity $(\mathrm{P}<0.05)$ of LPS-activated macrophages as compared to the LPS-activated positive control (Fig. 3B). This stimulation was concentration dependent. 

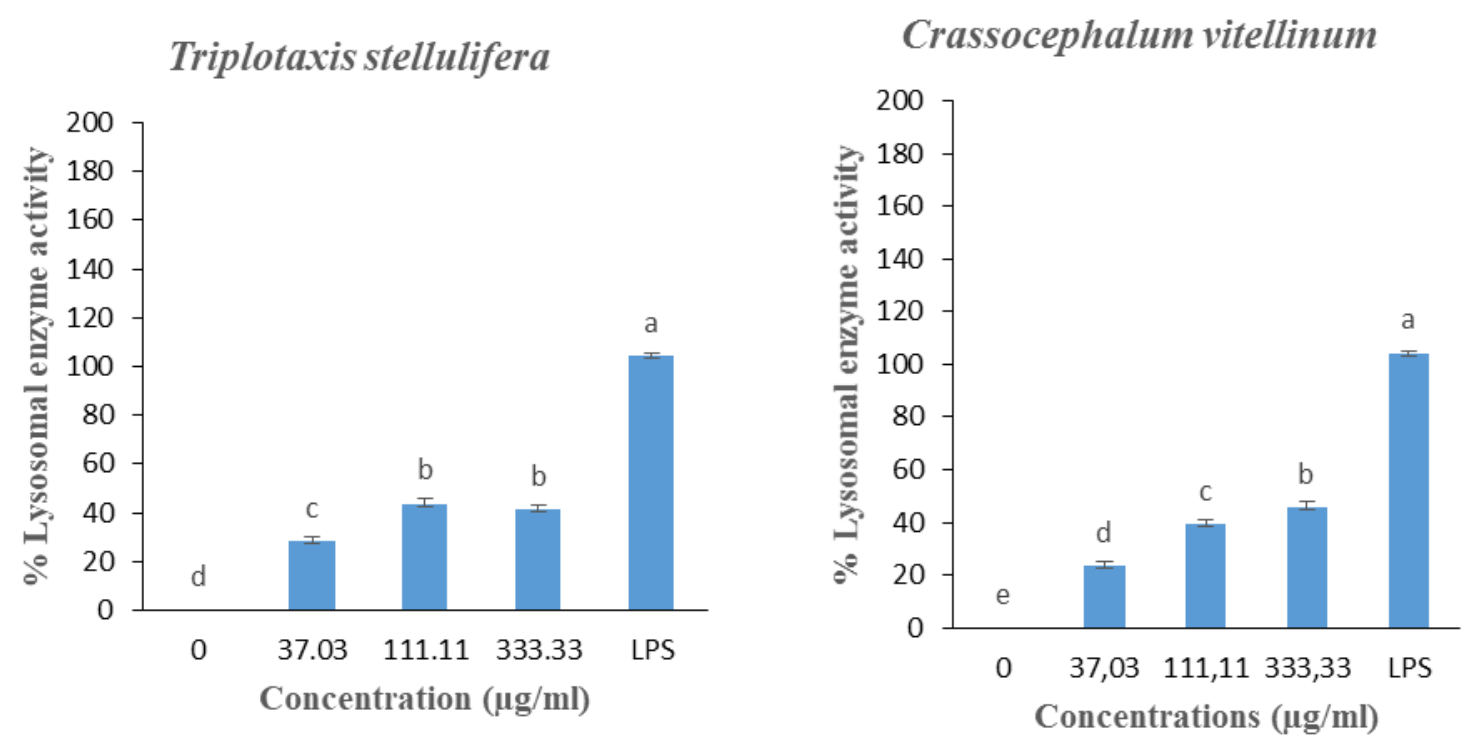

B

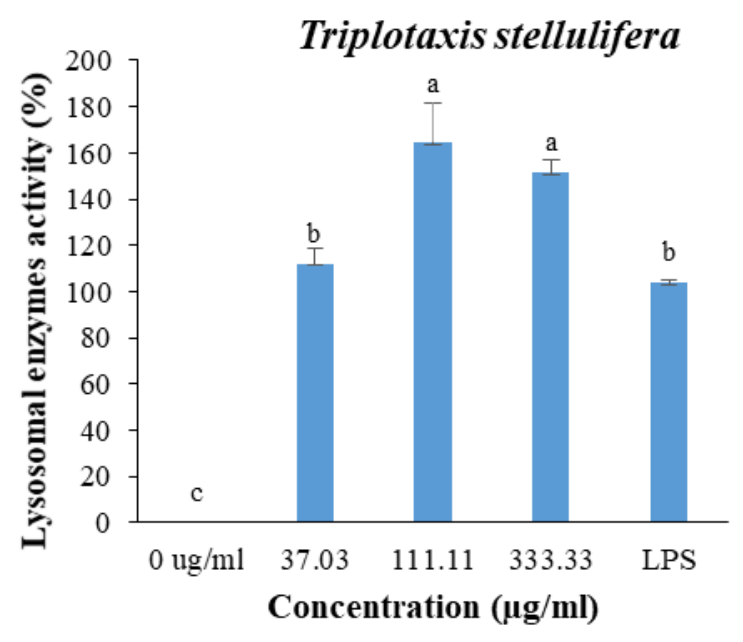

Crassocephalum vitellinum

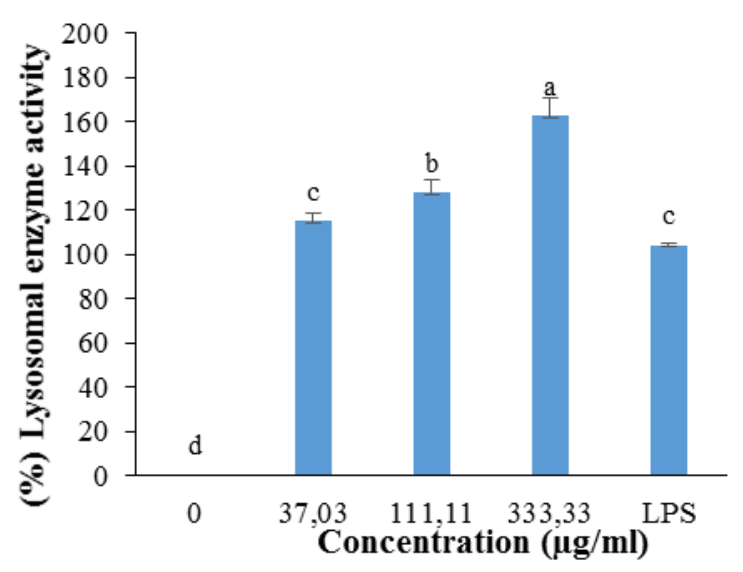

Fig. 3 - Effect of $T$. stellulifera and C. vitellinum extracts on macrophage lysosomal enzyme activity. Results are expressed as mean $\pm \mathrm{SD}(\mathrm{n}=3)$. For a given extract, values of concentration bearing different superscript letters are significantly different according to Waller-Duncan test (at P<0.05). A: Non-activated (LPS-nä̈ve) cells. B: LPS-activated cells. 


\subsection{Effect of plant extracts on Nitroblue Tetrazolium dye reduction}

The results of the NBT dye reduction assay presented in Table 1 show that there is no significant increase in NBT dye reduction by unactivated LPS-naive macrophages, except in the case of treatment with $T$. stellulifera at the highest concentration.

Table 1: Effect of methanol extracts of $T$. stellulifera and $C$. vitellinum on NBT dye reduction

\begin{tabular}{|c|c|c|c|c|}
\hline \multicolumn{5}{|c|}{ NBT reduction (\%) } \\
\hline \multirow{2}{*}{$\begin{array}{l}\text { Conc. } \\
(\mu \mathrm{g} / \mathrm{ml})\end{array}$} & \multicolumn{2}{|c|}{ Non-activated Macrophages } & \multicolumn{2}{|c|}{ LPS-activated macrophages } \\
\hline & T. stellulifera & C. vitellinum & T. stellulifera & C. vitellinum \\
\hline 0 & $67.84 \pm 1.44 \mathrm{c}$ & $67.84 \pm 1.44 \mathrm{~b}$ & $67.84 \pm 1.44 \mathrm{~d}$ & $67.84 \pm 1.44 \mathrm{~d}$ \\
\hline 37.03 & $68.53 \pm 6.33 c$ & $71.56 \pm 8.77 b$ & $132.43 \pm 1.66 \mathrm{~b}$ & $100.99 \pm 0.45 \mathrm{c}$ \\
\hline 111.11 & $60.27 \pm 4.82 \mathrm{c}$ & $64.63 \pm 12.88 b$ & $77.13 \pm 5.62 d$ & $111.44 \pm 3.42 b$ \\
\hline 333.33 & $82.42 \pm 2.74 b$ & $77.98 \pm 7.68 b$ & $144.91 \pm 6.74 \mathrm{a}$ & $143.68 \pm 2.93 \mathrm{a}$ \\
\hline LPS & $100 \pm 0.00 \mathrm{a}$ & $100 \pm 0.00 \mathrm{a}$ & $100 \pm 0.00 \mathrm{c}$ & $100 \pm 0.00 \mathrm{c}$ \\
\hline
\end{tabular}

Results are expressed as the mean \pm SD $(n=3)$. For a given extract, values of concentration bearing different superscript letters along the same column are significantly different according to Waller-Duncan test (at $\mathrm{P}<0.05$ ).

On the contrary, $T$. stellulifera and C. vitellinum methanol extracts significantly $(\mathrm{P}<0.05)$ increased NBT dye reduction of LPS-activated PEM as compared to the LPS-activated positive controls.

\subsection{Effect of plant extracts on the pinocytic activity of macrophages}

PEM pinocytic activity was evaluated by measuring the amount of neutral red taken up by LPS-activated and non-activated (LPS-naïve) macrophages. The level of neutral red uptake was significantly stimulated in LPS-naive (non-activated) PEM treated in the presence of both extracts as compared to non-treated (extract-naive) controls (Table 2). Also, the extracts of $T$. stellulifera and $C$. vitellinum significantly enhanced $(\mathrm{P}<0.05)$ the pinocytic activity of LPSactivated peritoneal macrophages as compared to the LPS positive controls (Table 2). 
Vol. 06, No. 01; 2021

ISSN: $2456-8643$

Table 2 - Effect of methanol extracts of $T$. stellulifera and $C$. vitellinum on pinocytosis activity of peritoneal macrophages.

\begin{tabular}{|c|c|c|c|c|}
\hline \multicolumn{5}{|c|}{ Pinocytic Index (PI) } \\
\hline \multirow{2}{*}{$\begin{array}{l}\text { Conc } \\
.(\mu \mathrm{g} / \mathrm{ml})\end{array}$} & \multicolumn{2}{|c|}{ Non activated Macrophages } & \multicolumn{2}{|c|}{ LPS activated macrophages } \\
\hline & T. stellulifera & C. vitellinum & T. stellulifera & C. vitellinum \\
\hline 0 & $1.00 \pm 0.00 \mathrm{c}$ & $1.00 \pm 0.00 \mathrm{c}$ & $1.00 \pm 0.00 \mathrm{c}$ & $1.00 \pm 0.00 \mathrm{~d}$ \\
\hline 37.03 & $1.00 \pm 0.0 \mathrm{c}$ & $1.06 \pm 0.05 b c$ & $1.15 \pm 0.01 \mathrm{~b}$ & $1.35 \pm 0.01 \mathrm{a}$ \\
\hline 111.11 & $1.06 \pm 0.05 b c$ & $1.01 \pm 0.00 \mathrm{c}$ & $1.32 \pm 0.02 \mathrm{a}$ & $1.09 \pm 0.00 \mathrm{~cd}$ \\
\hline 333.33 & $1.11 \pm 0.02 b$ & $1.08 \pm 0.02 b$ & $1.28 \pm 0.02 \mathrm{a}$ & $1.30 \pm 0.08 \mathrm{~b}$ \\
\hline LPS & $1.19 \pm 0.024 \mathrm{a}$ & $1.19 \pm 0.02 \mathrm{a}$ & $1.19 \pm 0.024 b$ & $1.19 \pm 0.02 b c$ \\
\hline
\end{tabular}

Results are expressed as the mean \pm SD $(n=3)$. For a given extract, values of concentration bearing different superscript letters along the same column are significantly different according to Waller-Dunkan test (at $\mathrm{P}<0.05)$.

\section{DISCUSSION}

Medicinal plants and their products are useful in disease treatment and maintenance of health, because of their various biological activities such as antioxidant, anti-ulcerogenic and immunomodulatory activities (Limem-Ben et al., 2009). Medicinal plants have been shown to inhibit or stimulate immune responses (Romani et al., 1994) through their action on immune cells such as macrophages. In the present study, we evaluated the immunomodulatory activity of Triplotaxis sellulifera and Crassocephalum vitellinum by measuring their abilities to enhance NO production, lysosomal enzyme activity, NBT dye reduction and pinocytic activity of peritoneal macrophages. This study demonstrated that the two extracts have no toxic effects on PEM, and that they stimulate NO production, lysosomal enzyme activity, NBT dye reduction and the pinocytic activity of LPS-activated macrophages.

Cell viability can influence test outcome thereby leading to false interpretation of the experimental result. Thus it is very important to assess the level of this viability before starting treatment with extracts. In this study, the isolated PEM were viable at $99 \%$ before experimental treatment with LPS and extracts. This cell viability can also be affected by several factors, including the experimental treatment with extracts. Hence, it is important to also assess cell viability after treatment with plant extracts (Kamtchueng et al., 2017). The MTT colorimetric assay was used in this regard. The amount of formazan generated following the reduction of MTT is directly proportional to the number of live cells (Kulkarni et al., 2001). No cytotoxicity was observed with both extracts. On the other hand, the T. stellulifera extract increased cell proliferation suggesting that it may also enhance macrophage activity. 
Activation of macrophages by bacteria lead to the production of large amounts of NO from L-arginine and molecular oxygen (Huang et al., 2002; Xingbin et al., 2007; Archana et al., 2009). This NO has many functions including antithrombotic, inflammatory, neurotransmission and vasodilatory functions. This study showed that $T$. stellulifera and $C$. vitellinum increased the levels of NO produced by activated macrophages. NO produced is toxic for microorganisms, tumour cells and it has been shown to be an important mechanism by which macrophages fight against microorganisms (Archana et al., 2009 ; Amolkumar and Archana, 2010).

Acid phosphatase has the capacity to generate reactive oxygen species (ROS). The increase in bacterial killing activity of macrophage is due to the enhancement of phosphatase activity which leads to the increase in production of ROS (Bune et al., 2001). Our study demonstrates that methanol extracts of $T$. stellulifera and $C$. vitellinum stimulate lysosomal enzyme activity of macrophages and thus can help enhance the destruction of microorganism through production of ROS.

Phagocytosis is a complex defense mechanism of the innate pathway of immunity, used by macrophages to neutralize and clear invading microorganisms. This phagocytic activity is usually accompanied by a burst of oxidative metabolism leading to the generation of oxygen species which can be detected through reduction of NBT dye (Benencia et al., 1999). The methanol extracts of $T$. stellulifera and $C$. vitellinum significantly increased NBT dye reduction of stimulated macrophages, indicating increased activity of oxidase enzymes following stimulation of phagocytes leading to the destruction of pathogens (Aurasorn et al., 1999).

Like phagocytosis, pinocytosis is also a mechanism of non-specific immunity exerted by macrophages, which leads to the destruction of pathogens through the reduction of oxygen to the superoxide anion, which is extremely toxic to ingested microorganisms ( Bosedasgupta and Pieters, 2014; Loegering and Lennartz, 2004). The pinocytic activity was evaluated by measuring the level of uptake of neutral red by extract-treated macrophages. Our result showed that the incorporation of neutral red by LPS-activated macrophages treated with extracts significantly increased, indicating an activation of the pinocytic activity of macrophages.

Penetration of a foreign agent into our body is follow by an activation of the immune system's defense. This results in an increase of innate and acquired immunities through different mediators (Wynn et al., 2013). The stimulation of non-activated (LPS-naïve) macrophages by treatment with $T$. stellulifera and $C$. vitellinum extracts demonstrated that the extracts can potentiate host innate defenses even in the absence of antigen in the body, hence they can be considered as immunogenic.

\section{CONCLUSION}

Globally, ours results provide evidence that the methanol extracts of Triplotaxis stellulifera and Crassocephalum vitellinum have stimulatory properties on non-specific immune responses mediated by macrophages; and also, that these extracts have no cytotoxic effects on peritoneal macrophages. These can somewhat justify the traditional use of these plants in folk medicine in Cameroon. However, more studies involving other cells of the immune system, as well as in-depth in vivo immunomodulatory, toxicological and molecular studies have to be done 
Vol. 06, No. 01; 2021

ISSN: $2456-8643$

in order to have more information about the activities of these extracts and their active ingredients.

\section{ACKNOWLEDGEMENT}

This work was supported by Intra ACP ARISE scholarship for African.

\section{CONFLICT OF INTEREST}

Authors declare that, there is no conflict of interest.

\section{REFERENCES}

Brown KL, Cosseau C, Gardy JL, Hancock RE. 2007. Complexities of targeting innate immunity to treat infection. Trends Immunol., 28 (6) 260-6.

Muralidharan S, Mandrekar P. 2013. Cellular stress response and innate immune signaling: Integrating pathways in host defense and inflammation. J. Leukoc. Biol., 94 (6) 1167-1184.

Nagy G, Koncz A, Telarico T, Fernandez D, Ersek B, Buzas E, Perl A. 2010. Central role of nitric oxide in the pathogenesis of rheumatoid arthritis and systemic lupus erythematous. Arthritis. Res. and Ther., 12 (3) 210.

Posadas I, Terencio MC, Guillen I, Ferrandiz ML, Coloma J, Paya M, Alcaraz MJ. 2000. Coregulation between cyclooxygenase- 2 and inducible nitric oxide synthase expression in the timecourse of murine inflammation. Arch. Pharmacol., 361 (1) 98-106.

MacMicking J, Xie Qw, Nathan C. 1997. Nitric oxide and macrophage function. Ann. Rev. immunology., 15 (1) 323.

Liu L, Li H, Xu RH, Li PL. 2017. Expolysaccharides from Bifidobacterium animalis RH activates RAW 264.7 macrophages through toll-like receptor 4. Food Agr. Immunl., 28 (1) 14961.

O'Brien K, Fitzgerald DC, Naiken K, Alugupalli KR, Rostami AM, Gran B. 2008. Role of the innate immune system in autoimmune inflammatory demyelination. Curr. Med. Chem., 15 (11) 1105-1115.

Kang S, Min H. 2012; Ginseng the 'Immunity Boost': The Effects of Panax ginseng on Immune System. J. Ginseng. Res., 36 (4) 354-368.

Pattanayak SP, Mazumder PM. 2011. Immunomodulatory Activities of Dendrophthoe falcata (L.f) Ettingsh in Experimental Animals: In vitro and In vivo Investigations. J. sci. res., 3 (3) 629640.

Kamtchueng MO, Mouokeu RS, Tume C, Djafoua YM, Kuiate JR. 2013. Evaluation of the immunomodulatory activity of the methanol extract of Alchemilla kiwuensis Engl. Int. J. Biol. Pharm. Res., 4 (5) 349-355.

Raymond SM, Rosalie ANN, Christopher T, Monique OK, Guy SSN, Dzoyem JP, Jean De Dieu T, Jules-Roger K. 2013. Immunomodulatory of Ethyl Acetate Extract and Fractions from leaves of Crassocephalum bauchience. Pharmacologia, 4: 38-47.

Stockert JC, Blázquez-Castro A, Caňete M, Horobin RW, Villanueva A. 2012. MTT assay for cell viability: Intracellular localization of the formazan product is in lipid droplets. Acta. Histochem., 114 (8) 785-79.

Romani N, Gruner S, Brang D, Kampgen E, Lenz A, Trockenbacher B, Konwalinka G, Fritsch 
Vol. 06, No. 01; 2021

ISSN: $2456-8643$

PO, Steinman RM, Schuler G. 1994. Proliferating dendritic cell progenitors in human blood. $J$. Exp. Med., 180: 83-93.

Suzuki I, Tanaka H, Kinoshita A, Oikawa S, Osawa M, Yadomae T. 1990. Effect of orally administered beta-glucan on macrophage function in mice. Int. Immunopharmacol., 12: 675-684. Manosroi A, Saraphanchotiwitthaya A, Manosroi J. 2006. Effects of Pouteria cambodiana extracts on in vitro immunomodulatory activity of mouse immune system. Fitoterapia, 77 (3): 189-193.

Repetto G, del Peso A, Zurita JL. 2008. Neutral red uptake assay for the estimation of cell viability/cytotoxicity. Nat. Protoc., 3 (7):1125-1131.

Limem-Ben AI, Skandrani I, Boubaker J, Ben SM, Neffati A, Bhouri W, Bouhlel I, Chouchane N, Kilani S, Guedon E, Ghoul M, Ghedira K, Chekir-Ghedira L. 2009. Investigation of the biological activity of polar extracts isolated from Phlomis crinita Cav ssp. mauritanica Munby. Drug. Chem. Toxicol., 32: 38-46.

Monique OK, Raymond SM, Simth SL, Christopher TB, Jules-Roger K. 2017. Immunomodulatory activity of methanol extract and fractions from Borreria verticillata on macrophages and lymphocytes. In. J. Adv. Pharm. Biol. Chem., 6 (1) 2277-2287.

Kulkarni SR, Sanjay NM. 2001. Extraction isolation and pharmacological evaluation of naturally occurring pheophytin "A" from Adhatoda vasica nees. Indian Drugs; 38 (4):164-169.

Huang J, DeGraves FJ, Lenz SD, Gao D, Feng P, Li D, Schlapp T, Kaltenboeck B. 2002; The quantity of nitric oxide released by macrophages regulates Chlamydia-induced disease. Proc. Natl. Acad. Sci., 99 (6): 3914-3919.

Xingbin Y, Yan Z, Haifang W, Qibing M. 2007. Macrophage Activation by an Acidic Polysaccharide Isolated from Angelica sinensis (Oliv.) Diels. J. Biochem. Mol. Biol., 40 (5): 636343.

Archana RJ, Amolkumar KH, Sachin SS, Vivek AC. 2009. In vitro and in vivo evaluation of immunomodulatory activity of methanol extract of Momordica charantia fruits. Drug Invent. Today., 1(2): 89-94.

Amolkumar KH, Archana RJ. 2010. Evaluation of immunomodulatory effects of methanol extract of Elaeocarpus ganitrus seeds. J. Nat. Remedies., 10 (1) 1-10.

Bune AJ, Hayman AR, Evans MJ, Cox TM. 2001. Mice lacking tartrate resistance acid phosphatase (Acp 5) have disordered macrophages inflammatory responses and reduce clearance of the pathogen, Staphylococcus Aureus. Immunology, 102: 103-113.

Benencia F, Courreges MC, Coulombie FC. 1999. Effect on the phagocytic activity and respiratory burst response of peritoneal macrophages. Immunophar., 41: 45-53.

Aurasorn S, Kornkanok I, Pattana S. 1999. Effect of Bacopa monniera Linn. extract on Murine Immune Response In Vitro Phytotherapy Research. Phytother., 22: 1330-1335.

Bosedasgupta S, Pieters J. 2014. Inflammatory stimuli reprogram macrophage phagocytosis to macropinocytosis for the rapid elimination of pathogens. PLoS. Pathog., 10(1): e1003879. Doi: 10.1371/journal.ppat.1003879.

Loegering DJ, Lennartz MR. 2004. Signaling pathways for Fc gamma receptor-stimulated tumor necrosis factor-alpha secretion and respiratory burst in RAW 264.7 macrophages. Inflammation, 28 (1) 23-31.

Wynn TA, Chawla A, Pollard JW. 2013. Macrophage biology in development, homeostasis and disease. Nature, 496 (7446) 445-55. 